DALAT UNIVERSITY JOURNAL OF SCIENCE Volume 12, Issue 1, 2022 78-112

\title{
IMPACT OF EXTENSIVE READING ON SOPHOMORE ENGLISH MAJORS' READING COMPREHENSION DEVELOPMENT AT DALAT UNIVERSITY
}

\author{
Nguyen Thi Thao Hien ${ }^{{ }^{*}}$, Nguyen Thi Tuong $V^{a}$ \\ ${ }^{a}$ The Faculty of Foreign Languages, Dalat University, Lam Dong, Vietnam \\ ${ }^{*}$ Corresponding author: Email: hienntt@dlu.edu.vn \\ Article history \\ Received: December 31 $1^{\text {st }}, 2020$ \\ Received in revised form: May $21^{\text {st }}, 2021 \mid$ Accepted: May $26^{\text {th }}, 2021$ \\ Available online: July $22^{\text {nd }}, 2021$
}

\begin{abstract}
This paper reports on an extensive reading program utilizing graded readers and the Moodle Reader for sophomore English majors at Dalat University. The main purpose of the study was to determine the impact of such a program on student reading abilities and to explore their attitudes toward the program. Data were collected from pretests, posttests, and questionnaires. Findings indicated that the extensive reading program was largely responsible for the higher mean gain on the posttest made by the experimental group, and that the majority of students expressed positive opinions toward the program. The paper concludes by putting forward some pedagogical implications on the implementation of such a program with English language students and lecturers in their courses of reading.
\end{abstract}

Keywords: Extensive reading; Graded readers; Moodle Reader; Reading attitudes; Reading capacities.

DOI: http://dx.doi.org/10.37569/DalatUniversity.12.1.818(2022)

Article type: (peer-reviewed) Full-length research article

Copyright $@ 2021$ The author(s).

Licensing: This article is licensed under a CC BY-NC 4.0 


\section{INTRODUCTION}

\subsection{Background}

Reading is an essential receptive skill for students to master since they need to acquire much of their academic knowledge by reading written English materials. In the tertiary English curriculum at Dalat University, reading, one of the compulsory subjects, mainly focuses on developing reading skills and strategies to help students read and comprehend various types of written materials for their future jobs, academic studies, or further education. In the reading classroom, the reading teachers typically do intensive reading with their students, who are required to apply specific skills and strategies to complete exercises, activities, or tasks on reading passages. However, students do not have adequate reading exposure to improve their reading abilities, and these skills and strategies are not sufficient to help them improve their overall reading ability. Some reading teachers, therefore, have encouraged students to read extensively to improve their reading comprehension and proficiency. However, a majority of students find it a daunting task to read further outside the classroom due to their inability to find reading sources of an appropriate reading level, which is actually a hindrance to the development of their reading motivation. In addition, being overloaded with heavy class schedules and not having an efficient way to monitor students' reading progress deters most of the reading teachers from promoting their students' reading competence. The authors, thus, have a strong desire to solve these problems by engaging students in an additional extensive reading program and to find its influence on students' reading comprehension development.

\subsection{Aims of the research}

This study was firstly conducted to examine the influence of extensive reading (ER) on the development of sophomore English majors' reading abilities at Dalat University. It then aimed to investigate the attitudes of the students in the experimental group toward extensive reading, upon which some pedagogical implications for an additional extensive reading program for English language students at Dalat University can be drawn. To achieve these aims, the present study was carried out to address the following two research questions:

- Are there significant differences in the reading comprehension scores of students exposed to ER compared to those given traditional instruction?

- What are the attitudes of the students who participate in the ER program?

\subsection{Research significance}

This research is significant for all English teachers attempting to improve English majors' reading abilities. It simultaneously brings attention to the need for the inclusion of extensive reading in our intensive reading curriculum, making it highly motivating and leading students to enjoy reading and to become independent and lifelong readers. In addition, the findings of this study will contribute to the current literature on ER by 
providing insights into ER in the English as a Foreign Language (EFL) context at Dalat University.

\section{LITERATURE REVIEW}

\subsection{Graded readers}

Graded readers are short books of fiction or nonfiction genres, especially written or simplified for foreign learners of English to read for factual information, language learning, and enjoyment (Bassett, 2010). The graded readers include versions of classics, modern novels or short stories, science fiction, thrillers adapted from best-selling writers, travel guides, and novels based on popular movies or TV shows. Graded readers are written using only the grammatical structures and vocabulary accessible to learners at their current level of linguistic competence. This grading ensures that learners can read with relative fluency without being overwhelmed by unfamiliar structures and vocabulary.

\subsection{Definitions of extensive reading}

As an approach to language teaching, ER has been applied in various sociocultural and educational settings; hence, it is "hard to reduce it to a dictionary-type definition," as stated by Day and Bamford (1998, p. 68). However, it is still crucial to consider the dictionary-type definitions in the most relevant literature.

- ER: An approach to the teaching and learning of reading in which learners read large quantities of material that are within their linguistic competence (Grabe \& Stoller, 2011, p. 286).

- $\quad$ ER means reading a large amount of texts in the L2 (second language). This is the very essence of the procedure, and all benefits are based on it (Day \& Bamford, 1998, p. 84).

- $\quad$ ER means reading in quantity and in order to gain a general understanding of what is read. It is intended to develop good reading habits, to build up knowledge of vocabulary and structure, and to encourage a liking for reading (Richards \& Schmidt, 2002, p. 193).

Three characteristics of ER emerge from these definitions: a large quantity of reading, materials within readers' linguistic competence, and pleasure.

\subsection{Research on extensive reading in foreign language settings}

Researchers of ER programs are very positive about the role ER plays in both improving reading skills and developing learners' language. There have been a number of studies of ER in both English as a Second Language (ESL) and EFL situations from a range of countries at all levels, from primary to university, and from adolescents to adults. This large amount of experimental research demonstrates gains in reading ability, i.e., 
reading, writing, listening, speaking, grammar, vocabulary, spelling, and gains in motivation and attitudes.

As for gains in reading ability, Elley and Mangubhai (1983) conducted a two-year study called the "Book Flood" project on nearly 400 primary school students in Fiji. Results at the end of the first year showed that the students receiving extensive reading had made a substantial improvement in receptive skills (reading and word recognition). Gains were also made in the students' writing abilities without students being given particular writing tasks. In addition, Lai (1993) found that in a four-week summer extensive reading program in Hong Kong, the students displayed gains in their reading performance in English. Masuhara et al. (1996) compared the effectiveness of strategies training and extensive reading in second language comprehension of first-year English majors in a Japanese women's university over eight weeks. Extensive reading was found to be more effective in improving students' reading comprehension. A study conducted by Lituanas et al. (1999) showed improvement in reading proficiency, reading speed, and accuracy among secondary school students in the southern Philippines. Similarly, Taguchi et al. (2004) reported an increase in reading fluency, reading rate, and reading comprehension among Japanese university students majoring in linguistics in Tokyo. Recently, Robb and Kano (2013) reported on a large-scale implementation of extensive reading in a university setting in Japan where all students were required to read outside class time as part of their course requirements. The results showed that students who did extensive reading outside the classroom as additional work achieved higher reading scores compared to those who were not required to do so.

As for gains in listening and speaking abilities, Cho and Krashen (1994) reported that, as a result of reading novels for pleasure, their four adult participants increased competence in both listening and speaking skills. Regarding improvement in grammar, Elley and Mangubhai (1983), and Hafiz and Tudor (1989) similarly reported the development of grammatical accuracy in English among low-intermediate level female university students in Japan. Some investigations indicate that ER is linked to students' gains in vocabulary. Pitts et al. (1989) conducted two experiments with adult ESL students in the United States and reported that second language learners could acquire vocabulary incidentally from extensive reading. Furthermore, Waring and Takaki (2003), in examining the amount of English vocabulary learned from reading graded readers by intermediate-level female learners in Japan, found that vocabulary could be learned incidentally. The influence of ER also extends to students' spelling proficiency. Day and Swan (1991) studied the impact of reading for meaning on spelling by Japanese university EFL learners and revealed that their subjects accurately spelled more of the words on a posttest than the control group. In other research, Polak and Krashen (1988) investigated the reading habits of community college ESL students in the United States and found that the more students read, the better their spelling was.

With regard to affective reasons that help extend language proficiency, it is widely agreed that ER can develop positive attitudes and a strong motivation to read, which has long been acknowledged as being very important in improving student performance (Baker et al., 1996; Guthrie \& Alvermann, 1999; Guthrie \& Knowles, 2001; Taylor \& 
Adelman, 1999). Once students have a positive attitude and confidence in their reading, they are likely to read more and develop autonomy, which helps them succeed in L2 learning. Researchers of ER programs subsequently were very positive about the role such an approach can play in improving learners' motivation, and the results of these studies show how students' attitudes changed toward reading in the L2 and how they became eager readers. Robb and Susser (1989) reported positive attitudes of Japanese university students who had engaged in extensive reading. In addition, Elley (1991) reported that students in Singapore seemed to develop "very positive attitudes toward books as they raised their literacy levels in English" (p. 397). Subsequently, Cho and Krashen (1994), in conducting a study of extensive reading on adults in the USA, found that the attitudes of their four subjects toward reading in English changed dramatically as a result of reading books from some of the popular Sweet Valley series written for young native speakers. The subjects quickly became motivated to read, discovering the pleasure that reading could bring. In another study, Rodrigo (1995) reported that the 27 Englishspeaking university students in a Spanish as a foreign language program in the United States developed "extraordinary positive reactions" toward the extensive reading program (p. 12). Recently, Tamrackitkun (2010) conducted a four-month investigation on the attitudes of Thai EFL students after exposure to extensive reading at Rajamangala University of Technology Thanyaburi. The findings provided conclusive evidence of students' positive attitude towards ER. In sum, the research review discloses that ER has been found to effectively develop learners' reading comprehension in EFL/ESL situations. Students show enhanced writing skills, improved speaking and listening skills, greater grammatical accuracy, larger vocabularies, improved spelling, and higher levels of motivation, as well as more positive attitudes towards foreign language learning.

The literature clearly shows that research in ER in the last three decades has reported manifold benefits to L2/FL learners. However, most empirical studies of ER in foreign language settings have been based on replacement approaches in the classroom and substantially impacted students' reading performance, while the effects of additive ER conducted outside the classroom have rarely been addressed. Thus, the current study on a supplemental ER approach may make a contribution to our knowledge of the numerous benefits that accrue from ER in EFL contexts.

\section{METHODOLOGY}

\subsection{Design}

The research design used in the present study is a quasi-experimental one in which both the control and experimental groups include student subjects in reading classrooms. Four entire classes, two classes as the experimental group $(\mathrm{N}=71)$ and two others as the control group $(\mathrm{N}=65)$, were asked to take a pretest to determine their reading level. After the ER program, both groups took a posttest. The scores of the pretest and posttest of the two groups were then statistically analyzed to determine if there were any significant differences between the scores of the two groups. An ER attitude questionnaire was subsequently conducted to explore students' attitudes in the 
experimental group towards the ER program, what benefits they gained, and what problems they encountered with it.

\subsection{Participants}

The research involved the participation of four classes, including 136 sophomore English majors at Dalat University. All participants were between 19 and 22 years of age and studied English as a foreign language at the Faculty of Foreign Languages. The reading classes ranged in size from 35 to 40 students and met for four 55-minute sessions each week. The four classes were taught by two different teacher-researchers. As such, each teacher-researcher was in charge of teaching one control and one experimental class.

\subsection{Program materials}

\subsubsection{Graded Readers}

In the present study, 231 graded readers, including both fiction and nonfiction, were selected as the ER materials to be read by the experimental group as homework. The researchers endeavored to include a variety of books on interesting topics and content from which students could select and read.

The participants were informed of the level differences (Kyoto level) and how to choose books that correspond to their own reading levels as determined by their pretest scores. This is consistent with the assumption in ER literature that readers should, to some extent, have control over what they read. The reading goals for each level are displayed in detail in Table 1 below.

Table 1. The minimum number of words (goal) to read

\begin{tabular}{llll}
\hline Test scores & CEFR Scale & Kyoto Level & Goal (words) \\
\hline $0-9$ & A2 & 4 & 80,000 \\
$10-15$ & A2 & 5 & 120,000 \\
$16-20$ & B1 & 6 & 140,000 \\
$21-23$ & B1 & 7 & 160,000 \\
$24-36$ & B2 & 8 & 180,000 \\
$37-42$ & C1 & 9 & 200,000 \\
\hline
\end{tabular}

There was a minimum number of words the subjects must read during the term to get 1.5 out of 5 points for the reading assignment. If they did not reach the minimum number of words, they could not get their $30 \%$. To pace the students' quiz taking, so that they did not attempt to fulfill their reading requirement in the last few days or weeks of the term, the reading goal was divided into three deadlines, as shown in Table 2. 
Nguyen Thi Thao Hien and Nguyen Thi Tuong Vy

Table 2. Reading deadlines for student goals

\begin{tabular}{llll}
\hline Level & Deadline 1 & Deadline 2 & Deadline 3 \\
\hline 4 & 26,000 & 52,000 & 80,000 \\
5 & 40,000 & 80,000 & 120,000 \\
6 & 46,000 & 92,000 & 140,000 \\
7 & 53,000 & 106,000 & 160,000 \\
8 & 59,000 & 118,000 & 180,000 \\
9 & 60,000 & 125,000 & 200,000 \\
\hline
\end{tabular}

\subsubsection{MReader}

MReader is a software program integrated with the Moodle course management system that was developed in 2007 by Thomas Robb, Professor at the Department of English, Kyoto Sangyo University and Executive of the Extensive Reading Foundation. It was created to allow the ER approach to be implemented in any class with access to graded readers. This program makes it possible for students to demonstrate that they have read their graded readers and to confirm their understanding of these books by means of timed quizzes available on MReader. MReader offers over 4,600 quizzes, each of which has 20-30 questions. Every student receives 10 randomized questions of four question types: multiple choice, who said this, true/false, and event ordering. Quizzes on nonfiction books mainly include multiple choice and true/false items. MReader makes it convenient for teachers to monitor their students' reading goals and frees them from the necessity of keeping track of what students have read via timeconsuming reports, book reflections, group discussions, picture drawings, or book summaries. MReader also presents itself as a powerful game-like motivator with leaderboards and links to Facebook. MReader is helpful in that it alerts students to take quizzes at the proper times to meet deadlines and provides a clear record of students' progress. In particular, there is no need for a teacher invigilator while students take quizzes. On the MReader site (mreader.org), each registered teacher has their own page with built-in functions that allow them to conveniently keep track of students' reading. The functions include students' names, starting levels, current levels, number of quizzes taken, quizzes passed or failed, total numbers of words read, and reading goals.

\subsection{Measures}

\subsubsection{Reading comprehension tests}

The main purpose of the present study is to investigate the effects of ER on students' reading comprehension. It is, therefore, indispensable for the researchers to carefully select the test texts in order to measure students' reading comprehension. The selection of the test texts must meet the readability criteria on the basis of their topic relevance to the subjects, the suitability of contents, and the right level of difficulty for the students (Seymour \& Walsh, 2006). 
The researchers decided to employ the FCE reading test, which is a standardized test of English at Level B2 on the CEFR-VN scale. The choice of the reading test (pretest and posttest) must be consistent with FCE texts in the course content to help students achieve the VSTEP standard reading levels. Accordingly, an FCE reading test consists of four parts on a wide range of different topics with a total of three 1,800-word to 2,000word texts of progressively difficult levels. The maximum score is 42 , and the test corresponds to CEFR reading levels of $\mathrm{A} 2$ to $\mathrm{C} 1$.

\subsubsection{ER attitude questionnaire}

In this study, a questionnaire was used as one of the data collection tools. The purpose of the questionnaire analysis is to see whether the experimental group had positive attitudes toward ER, perceived benefits from it, or faced any problems with it during the experiment. The questionnaire structure consisted of 38 items with a Likert scale from 1 to 5 and 2 open-ended questions. Half of the 38 items were paraphrases of the others, designed to examine the reliability of the 19 original items. Participants were asked to rate each item from "strongly disagree" (1 point), to "strongly agree" (5 points). To assess student attitudes toward ER, the questionnaire content focused on two aspects: one pertaining to the improvement in reading skills as an effect of ER (items 1, 2, 3, 4, 5, $6,7,9,10$, and 12) and the other pertaining to student feelings about ER (items 8, 11, 13, $14,15,16,17,18$, and 19). Two open-ended questions looked at problems that students experienced during the program and their recommendations on how such a program could be improved. To help participants understand the items clearly, the researchers clarified the meaning of particular items on the questionnaire for the participants.

\subsection{Procedures}

The study was conducted over a period of twelve months. In the first phase, a pilot study was undertaken to gain insights into the operation of MReader and to investigate the appropriateness of the graded readers for the sophomore English majors. The experimental study was carried out in the second phase. During this time, the two groups - the control group and the experimental group - received each week the same four 55minute sessions of intensive reading, emphasizing the construction of meaning from texts and the development of reading skills.

The experimental group engaged in additional extensive reading of a variety of materials on a wide range of topics of their interest and within their current reading level. Guidelines, including the purpose of ER, the procedure of borrowing books and taking quizzes, the level system, and the promotion and evaluation scheme, were explained to the subjects before the program. Their understanding of the reading was demonstrated through the quizzes on the MReader website (mreader.org). Their reading goals were monitored weekly and help was offered accordingly. To determine students' reading levels and their reading scores after exposure to additional extensive reading, a pretest and posttest were used. To ensure that students did their best on the tests, students were informed that the pretest and posttest would be marked as in-class assignments. Finally, 
both qualitative and quantitative methods were employed to gain insights into the impact of the ER approach on students' reading comprehension.

\subsection{Methods of data analysis}

Regarding the analysis of the reading scores, descriptive statistics were used to present the mean, mode, median, and standard deviation of the test results in the two reading comprehension tests. First, the paired samples $t$-test was conducted to trace the mean difference between the pretest and posttest within each group. Second, the independent samples $t$-test was carried out to find whether the experimental and control groups had equal reading ability prior to the ER program. Subsequently, the same statistical analysis, the independent samples $t$-test, was used to determine whether there were any statistically significant differences between the posttest reading scores of the control and experimental groups that can be attributed to the influence of the ER program. Simultaneously, effect size, a measure to determine the magnitude of the difference, was also reported. Finally, the distributions of the pretest and posttest scores were analyzed and input into Excel 2010 to provide insight into the improvement in reading proficiency levels achieved by each group during the experiment. For analysis of the questionnaire answers, SPSS software was used to calculate the percentages of the students' answers (Likert numbers) for each item.

\section{RESULTS AND DISCUSSION}

The findings in this study indicated a substantial improvement in sophomore English majors' reading abilities and their positive attitudes toward the ER program at Dalat University. This greatly reinforces the results from a body of research that ER leads to gains in reading abilities and favorable attitudes.

\subsection{Comparison of student pretest and posttest performance within and between groups}

\subsubsection{Comparison of the pretest and posttest means within each group}

A paired samples $t$-test was carried out to compare the mean scores attained on the pretest and posttest by students in the control group. Table 3 presents the results of the paired samples $t$-test conducted for this purpose. As shown in the table, there was a significant difference in the scores of the pretest $(M=17.25, \mathrm{SD}=6.26)$ and the posttest $(\mathrm{M}=19.62, \mathrm{SD}=7.38)$ of the control group with $t(64)=-3.03, \mathrm{p}<0.05$, and Sig. (2tailed $)=0.004$. Clearly, the students in the control group performed better in the posttest, earning higher mean scores (19.26 compared to 17.25). The results indicate that students given the traditional instruction made a certain improvement in their reading ability. Their progress was not due to chance alone since the Sig. (2-tailed) value is 0.004 , which is lower than the 0.05 significance point. Therefore, this improvement can be attributed to the students' attainment of knowledge, reading skills, and strategies during their formal study of intensive reading. 
Table 3. Paired samples $t$-test for comparing the mean scores of the pretest and the posttest performed by the control group

\begin{tabular}{lllllll}
\hline Test Variable & $\mathrm{N}$ & Mean & Std. Deviation & $\mathrm{t}$ & df. & Sig.(2-tailed) \\
\hline Pretest & 65 & 17.25 & 6.26 & -3.031 & 64 & .004 \\
Posttest & 65 & 19.62 & 7.38 & & & \\
\hline
\end{tabular}

$* \mathrm{p}<.05$

Similarly, a paired samples $t$-test was conducted to compare the mean scores on the pretest and the posttest achieved by students in the experimental group. Table 4 displays the results of the paired samples $t$-test carried out for this purpose. There was a significant difference in the scores of the pretest $(M=21.54, \mathrm{SD}=7.79)$ and the posttest $(\mathrm{M}=26.82, \mathrm{SD}=7.09)$ with $t(70)=-10.7, \mathrm{p}<.001$, and Sig. (2-tailed $=.000)$. Obviously, there was a large difference of 5.28 between the mean pretest and posttest scores for the experimental group. The difference is significant since the $p$ value is lower than 0.001 . Therefore, students' remarkable improvement in their reading ability in the experimental group is assumed to be influenced by both their learning experiences in the intensive reading program and their exposure to the ER program.

Table 4. Paired samples $t$-test for comparing the mean scores of the pretest and the posttest performed by the experimental group

\begin{tabular}{lllllll}
\hline Test Variable & $\mathrm{N}$ & Mean & Std. Deviation & $\mathrm{t}$ & $\mathrm{df}$. & Sig.(2-tailed) \\
\hline Pretest & 71 & 21.54 & 7.79 & -10.7 & 70 & .000 \\
Posttest & 71 & 26.82 & 7.09 & & \\
\hline \multicolumn{7}{c}{$* * \mathrm{p}<.001$} \\
\hline
\end{tabular}

In sum, the results of the paired samples $t$-test for each group indicate that both groups generally made a certain improvement after the three-month experiment. The improvement made by the experimental group, who engaged in the ER program, was considerably greater than that made by the control group, who followed the traditional instruction. There was a difference of 2.91 in the pretest and posttest means between the experimental group (5.28) and control group (2.36). Nevertheless, further statistical calculations are needed to determine which group truly outperformed in the posttest.

\subsubsection{Comparison of the performance between the control and experimental} groups on each test (pretest and posttest)

To evaluate the reading abilities of both groups before the experiment, an independent samples $t$-test was performed to compare the pretest means of both groups. Table 5 shows the results of the independent samples $t$-test conducted for this purpose. Before the three-month experimental period, there was a significant difference in the pretest scores of the control group $(\mathrm{M}=17.25, \mathrm{SD}=6.26)$ and the experimental group $(\mathrm{M}=21.54, \mathrm{SD}=7.79)$ with $t(132)=-3.5, \mathrm{p}<0.05$, and Sig. (2-tailed) $=0.001$. As can be seen from the table, the students in the experimental group outperformed those in the control group on the pretest with a higher mean score (21.54 compared to 17.25). The 
difference could be ascribed to the fact that there were better students in the experimental group that could have made them better readers of a second language.

Table 5. Independent samples $t$-test for comparing the control group and the experimental group on the pretest

\begin{tabular}{lllllll}
\hline Group Variable & $\mathrm{N}$ & Mean & Std. Deviation & $t$ & df. & Sig.(2-tailed) \\
\hline Experimental & 71 & 21.54 & 7.79 & -3.517 & 132 & .001 \\
Control & 65 & 17.25 & 6.26 & & & \\
\hline \multicolumn{7}{c}{$* \mathrm{p}<.05$} \\
\hline
\end{tabular}

Subsequently, an independent samples $t$-test was run to find out whether there was a statistically significant difference between the means of the two groups on the posttest. Table 6 shows a statistically significant difference in the posttest scores between the control group $(\mathrm{M}=19.62, \mathrm{SD}=7.38)$ and the experimental group $(\mathrm{M}=26.82, \mathrm{SD}=7.09)$ with $t(132)=-5.8, \mathrm{p}<.001$, and Sig. (2-tailed) $=.000$. As such, the mean gain of the experimental group was greater than that of the control group, 26.82 and 19.62, respectively. Besides, the scores of the experimental group were more homogeneous than those of the control group since the former's standard deviation is lower (7.09 compared to 7.38). Moreover, the Sig (2-tailed) value was lower than .001 ( $p<0.001)$. Thus, it can be concluded that the difference in the mean scores on the posttest for the two groups is statistically significant, i.e., not due to chance alone.

Table 6. Independent samples $t$-test for comparing the control group and the experimental group on the posttest

\begin{tabular}{lllllll}
\hline Group Variable & $\mathrm{N}$ & Mean & Std. Deviation & $t$ & df. & Sig.(2-tailed) \\
\hline Experimental & 71 & 26.82 & 7.09 & -5.8 & 132 & .000 \\
Control & 65 & 19.62 & 7.38 & & & \\
\hline \multicolumn{7}{c}{$* * \mathrm{p}<.001$} \\
\hline
\end{tabular}

Nevertheless, as one might assume that students in the experimental group, who had higher scores in the pretest, will be more likely to outperform students in the control group on the posttest, it was genuinely important to determine the magnitude of the difference, i.e., the so-called effect size (ES) on the experimental group. This is to ascertain whether the ER program greatly affects students' improvement or not. Thus, ES was calculated based on the following formula (Rubin, 2013).

$$
E S=\frac{\text { Experimental Group Mean-Control Group Mean }}{\text { Control Group Standard Deviation }}
$$

The guidelines for interpreting ES are: $\mathrm{d}<0.02=$ small effect, $\mathrm{d}: 0.50-0.79=$ moderate effect, and d >0.8 = large effect (Cohen, 1992, as cited in Rubin [2013]). The effect size for this analysis was 0.97 , which indicates that the effect of ER on students was large. Therefore, it can be logically concluded that a significant difference existed between the two groups in terms of reading comprehension after the three-month 
experiment. In other words, the higher gain in the mean score made by the experimental group must be largely the effect of the ER program.

To understand the shift in reading levels for each group during the experiment, we further explore the descriptive statistics for the pretest and posttest scores of both groups in the next section. experiment

4.1.3. Differences in gains and levels achieved by both groups during the

Table 7 below summarizes some significant descriptive statistics of the gains in reading proficiency achieved by both groups between the pretest and posttest.

Table 7. Descriptive pretest and posttest statistics for the experimental and control groups

\begin{tabular}{lllll}
\hline \multirow{2}{*}{ Descriptive statistics } & \multicolumn{2}{l}{ Experimental Group (N=71) } & \multicolumn{2}{l}{ Control Group (N=65) } \\
\cline { 2 - 5 } & Pretest & Posttest & Pretest & Posttest \\
\hline Mean & 21.54 & 26.82 & 17.25 & 19.62 \\
Mode & 14 & 24 & 12 & 12 \\
Median & 20 & 27 & 17 & 18 \\
Minimum & 8 & 13 & 7 & 7 \\
Maximum & 41 & 41 & 40 & 41 \\
Standard Deviation & 7.79 & 7.09 & 6.26 & 7.38 \\
\hline
\end{tabular}

As displayed in Table 7, the mean, mode, and median for the posttest scores are greater than those of the pretest scores in both groups. The scores of the control group ranged from 7 to 40 for the pretest and from 7 to 41 for the posttest, whereas the scores of the experimental group ranged from 8 to 41 for the pretest and from 13 to 41 for the posttest. Additionally, the posttest scores of the experimental group were more homogeneous than those of the control group since the standard deviation of the former is lower (7.09 compared to 7.38).

To gain a deeper insight into the proficiency levels students achieved in each group, descriptive statistics were employed to find the frequency of participants' scores. The pretest and posttest are assessed according to the CEFR scale - the Common European Framework of Reference for Languages which is a guideline used to describe achievements of foreign language learners across Europe and in other countries - with 42 points as the maximum for each test. Accordingly, students receiving less than 16 points were considered A2 level, students with 16-23 points were B1 level, students with 24-36 points were B2 level, and students with more than 37 points were considered $\mathrm{C} 1$ level.

Figure 1 compares the levels the participants in the control group obtained in the pretest and posttest. At the beginning of the semester, a large number of students were at the A2 and B1 levels; the percentages were $13.9 \%$ and $67.6 \%$, respectively. After the 
three-month experiment, the students with these levels decreased to $7.7 \%$ for A2 and $49.3 \%$ for B1. As for the B2 and C1 levels, the results show that $41.4 \%$ of the students attained the B2 level in the posttest compared to $16.9 \%$ in the pretest. A minimal percentage of students remained unchanged at the $\mathrm{C} 1$ level $(1.5 \%)$.

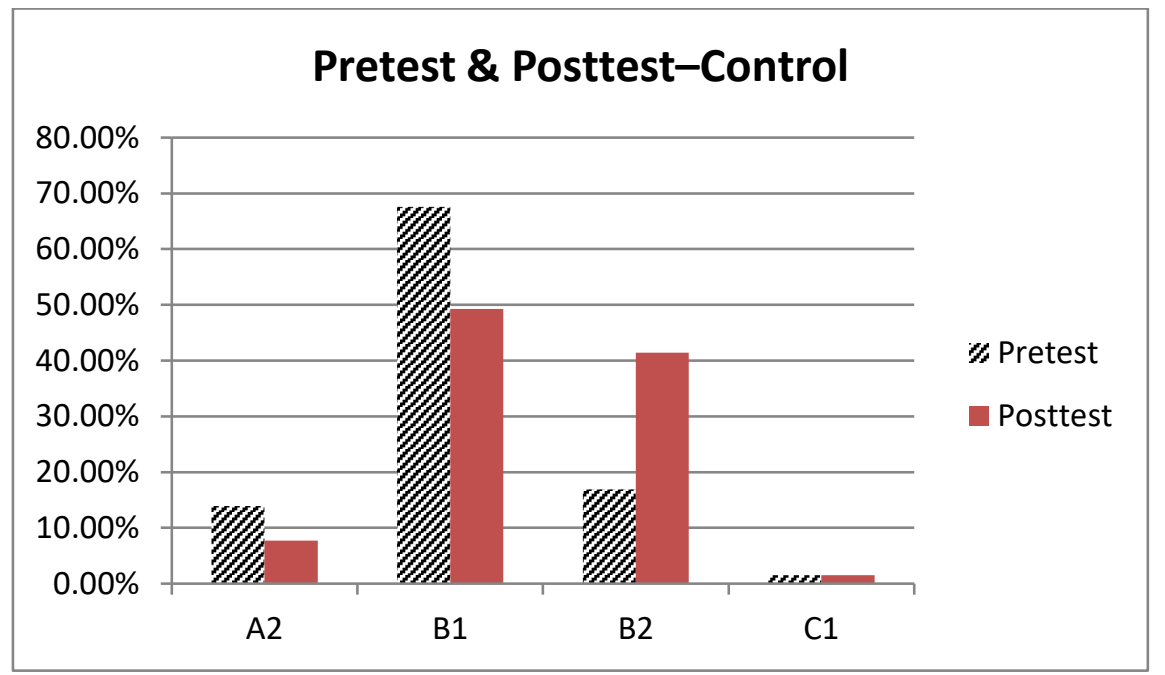

Figure 1. Participants' levels in the pretest and posttest - control group

A large number of students in the experimental group were in the A2 (2.8\%) and B1 (61.8\%) levels before the ER program (Figure 2). In comparison to the control group, this number decreased considerably, to only $29.40 \%$ at B1 and $0 \%$ at A2. The number of students attaining the B2 level nearly doubled, from $30.8 \%$ at pretest to $60.3 \%$ at posttest. Also, students who reached the $\mathrm{C} 1$ level rose to $9.8 \%$ in the posttest compared to $4.2 \%$ in the pretest.

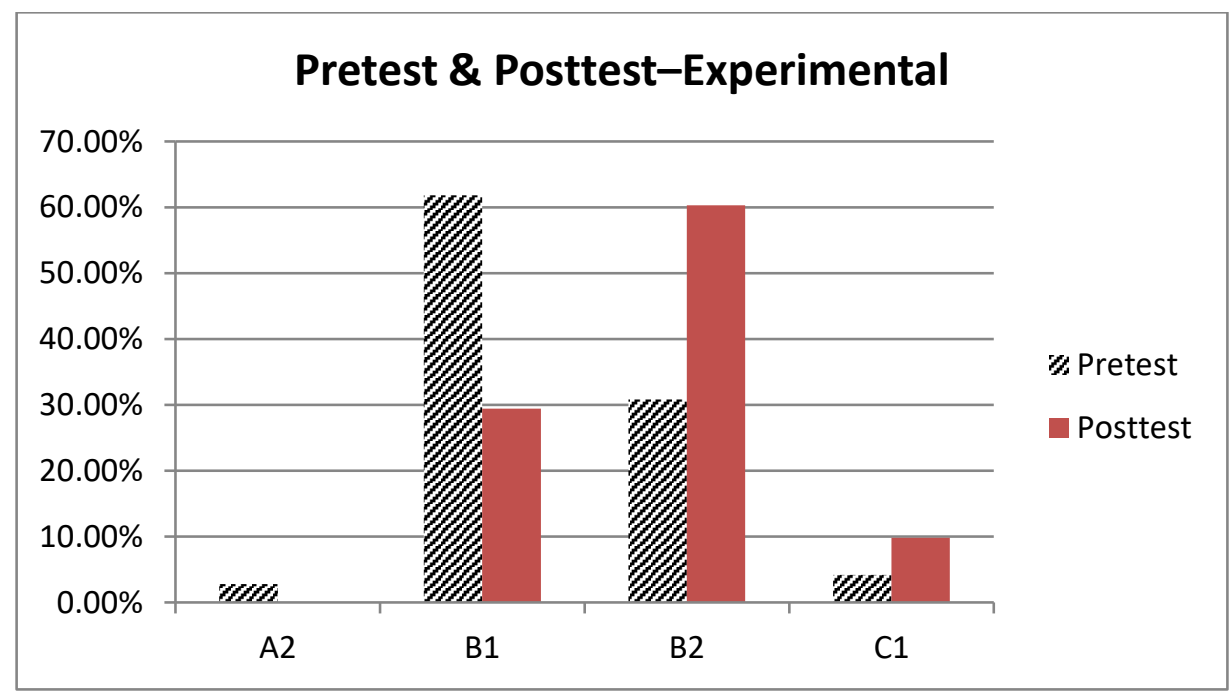

Figure 2. Participants' levels in the pretest and posttest - experimental group

Figure 3 shows the significant shift in proficiency levels that the students in the experimental group achieved compared to the control group. 


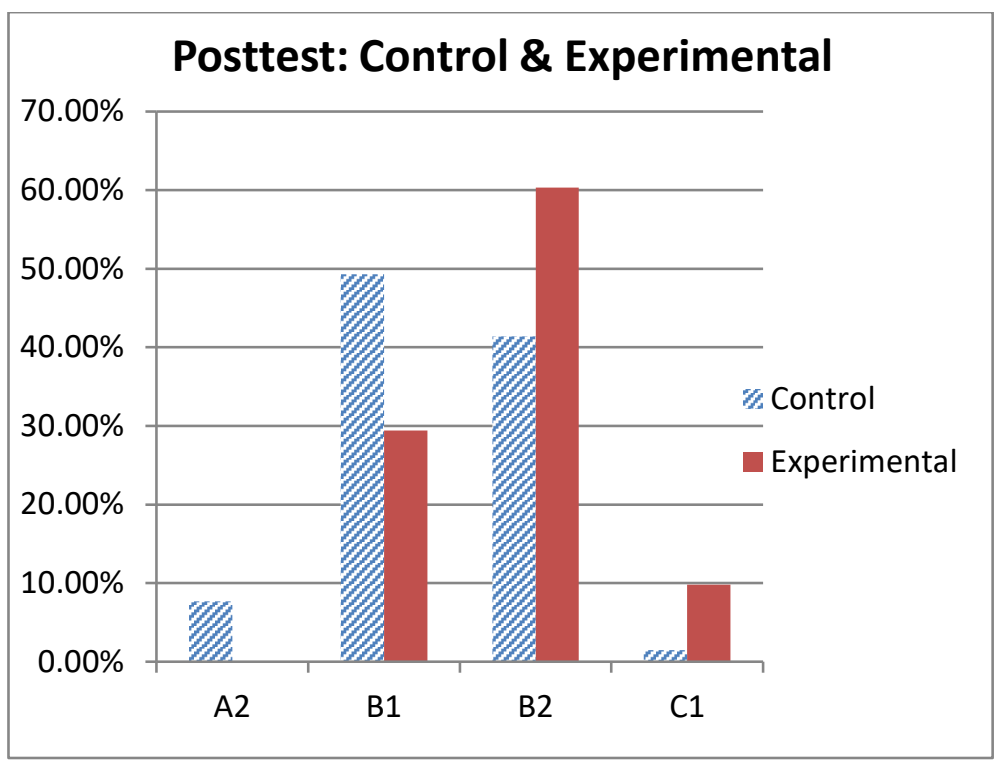

Figure 3. Participants' levels in the experimental and control groups - posttest

The results shown in Figure 3 indicate that a minimal percentage of participants (7.7\%) in the control group were still at the A2 level, the lowest level in the scale, while no participants were at this level in the experimental group. The number of students at the B1 level was still high (49.30\%) compared to those at the same level in the experimental group (29.40\%). As for the B2 and $\mathrm{C} 1$ levels, students in the experimental group outnumbered those in the control group with percentages of $70.1 \%$ and $43 \%$, respectively. The difference in reading level gains made by students in both groups at these two levels - B2 and C1 - is significant at $24.5 \%$ for the control group compared to $35.1 \%$ for the experimental group. To conclude, the ER program made a large improvement in students' levels of reading comprehension. These influences actually shifted more students to the $\mathrm{B} 2$ and $\mathrm{C} 1$ levels at the end of the course.

In summary, the comparison of both groups' gains in the pretest and posttest has helped us to answer the first question of the research. Accordingly, the experimental group obtained a greater mean score than the control group (26.82 compared to 19.62). This difference, as expected, was proved to be significant, with $t(132)=-5.8, \mathrm{p}<.001$, Sig. $(2$-tailed $)=.000$, and $d=0.97$. In other words, the students who engaged in the ER program were able to make more progress than those following the conventional instruction.

\subsection{Results and discussion of the questionnaire regarding attitudes toward extensive reading}

In this presentation of the results, the quantitative descriptive data are presented. Among the 71 experimental participants, only 60 of them filled in the questionnaire. The Cronbach Alpha test was performed to examine the reliability of the 38-item questionnaire; it showed a reliability of .703, which is acceptable. 
The findings shown in Figure 4 indicate that, overall, the majority of participants had positive attitudes towards ER.

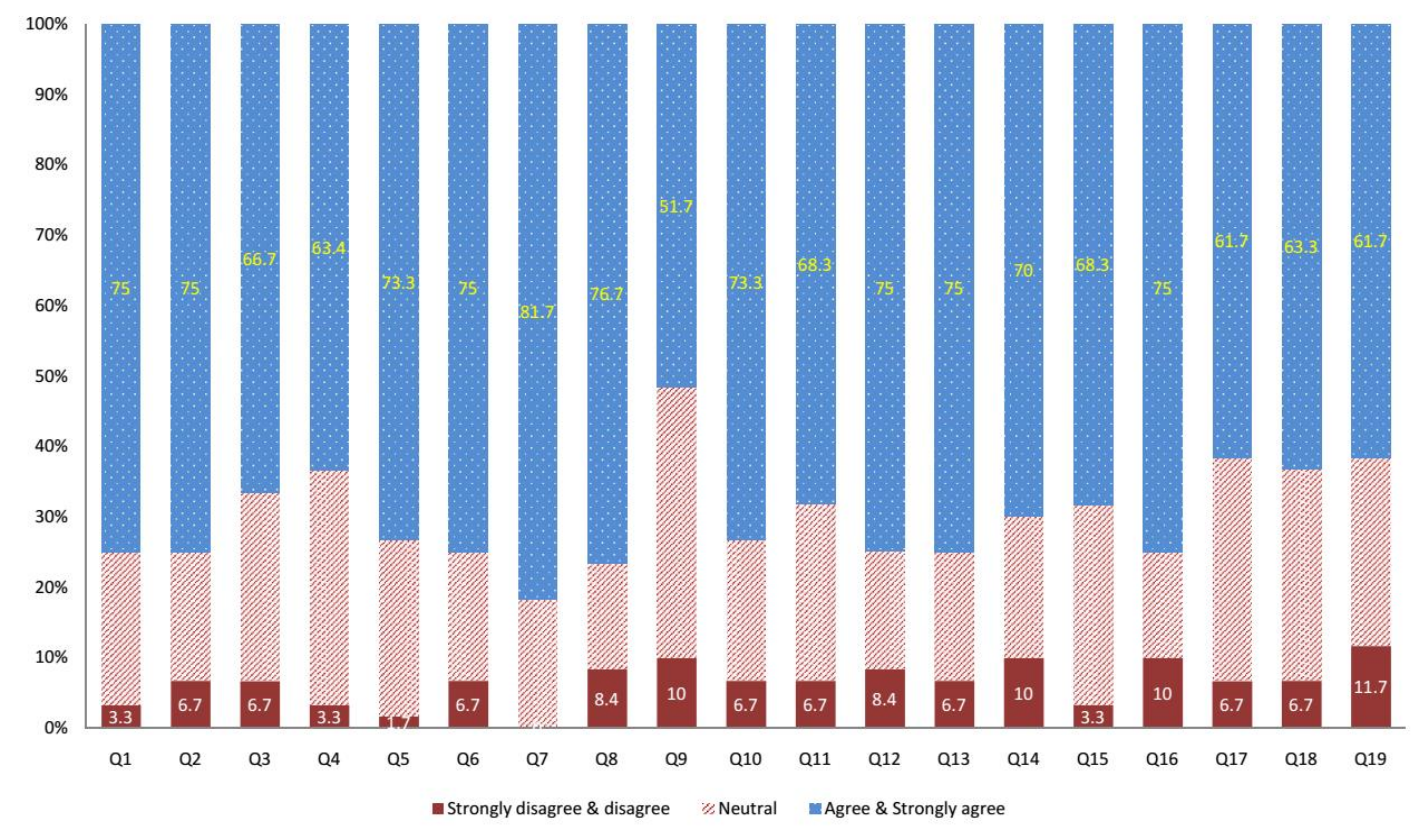

Figure 4. Frequencies of students' attitudes toward ER

As seen in Figure 4, the results revealed that the majority of the responses were positive for all 19 questions. Students' responses to the 19-item questionnaire indicated that a majority of them believed the ER approach helped them achieve gains in linguistic competence, e.g., building a large sight vocabulary (75\%), enhancing grammar knowledge $(75 \%)$, distinguishing the genres of writing and text structure $(66.7 \%)$, bringing out their prior knowledge into reading comprehension (63.4\%), expanding their background knowledge $(73.3 \%)$, applying what they had learned into practice $(75 \%)$, improving reading skills and strategies $(81.7 \%)$, reading the graded readers with ease and understanding the gist (76.7\%), increasing reading speed (73.3\%), and reading in English for general information $(75 \%)$.

A majority of the students also believed that the ER approach was interesting $(68.3 \%)$, gave them a chance to have further practice in reading English $(76.7 \%)$, and developed their reading habits $(68.3 \%)$. They also believed themselves to have made gains in self-confidence $(75 \%)$ and indicated that they would like this type of reading more $(70 \%)$ after exposure to the extensive reading program.

One of the possible reasons for these findings is that once students achieve improvement in their reading ability, they tend to have a positive attitude toward what they have experienced. The second possible reason is that extensive reading, involving graded readers especially written for beginning and intermediate level students, allows students to read without anxiety and difficulty and motivates them to read. However, as 
shown in the chart, a small percentage of students were still not in favor of this program for a number of reasons.

First, being accustomed to the traditional way of learning reading in which translation skills are frequently used, these students were probably conditioned to take as much time as necessary to understand every word of a text and to link progress and success with effort and hard work, with the result that such students may not be able to accept the reading of a great deal of relatively easy material as a legitimate academic activity. This goes against the important goal and the principle of extensive reading that to become fluent readers we need to build our sight vocabulary and read a large quantity of easy texts. Moreover, being used to the traditional roles of both teachers and students, they felt uneasy when the teachers only guided and they themselves had to make their own decisions on what, when, and where to read. In other words, they do not have sufficient maturity to work on their own for long periods without the presence of the teacher.

Second, a small number of participants could not manage their time reading graded readers. In fact, in the first two weeks of the course some complained a lot about the quantity of reading assignments, saying that they did not have enough time to read and were busy doing the assignments given by other course instructors.

Third, the participants did not have access to a large quantity and variety of books, as there were only 67 online books and 164 paperback books. This supply could not meet students' considerable reading demand, especially for books at levels 8 and 9. Apart from this, some of the students were not equipped with the necessary facilities to download online books. Besides, some of the online versions were not clearly scanned, which made them hard for students to read.

Fourth, the paperback books were not shelved in the school library but in the faculty's tutoring room. As such, the teachers had to ask one student from the experimental group to assist in monitoring the materials. This student, however, was not always available when books needed to be checked out. Furthermore, due to the limited number of books, one student could only check out one book at a time for one week, which made it inconvenient for students, especially when they would like to read more on their days off from school, or when they tried to reach a reading target not previously achieved because of certain personal problems.

Fifth, students had to wait 24 hours between the quizzes, while some books could be read in just two or three hours, which made it hard for them to retrieve the information from their short-term memories to correctly answer questions.

Taken together, the results show that a majority of students participating in the ER program held a positive attitude toward ER. Nevertheless, a minority of them still did not like to adopt this approach, being accustomed to the traditional method of teaching and learning reading, while other reasons are linked to students' lack of time management skills and unfavorable conditions of this ER program, such as book resources, availability and check-out procedures, and quiz-taking times. 


\section{RECOMMENDATIONS AND CONCLUSIONS}

Both the literature and the findings of this classroom research raise some interesting issues for teachers who expect to use an ER program effectively. First, an ER program demands commitment in terms of time, resources, and energy while being a challenge for students, especially those who are used to the traditional method. Teachers, therefore, should be sensitive, careful, and explicit in orientating students to the goals and methodology of ER at the start of the program and in explaining the benefits to students. When students themselves recognize the goals and the value of ER for their language development, they are more likely to be motivated to read more and consequently learn more. At the same time, this orientation process needs to be continued at appropriate intervals throughout the course until the students have truly made the principles and goals of ER their own. Second, the teacher must also ensure that there is a wide range of attractive, highly interesting, and relevant materials available, as student needs and interests are varied. For the convenience of students, graded readers should be kept in the library of the university where librarians are ready to help during office hours. Third, it is recommended that the time set between quizzes should be shortened to 12 hours instead of 24 hours by the web administrator to motivate eager and quick readers to do more reading. Finally, it is important to remember that learners are more likely to immerse themselves in reading extensively if constant support and careful monitoring take place. The evidence was shown in the case of students without time management skills turning to eagerness after repeated explanations of the importance of ER for language learning and tireless encouragement from the instructor.

The results of the study indicated that the extensive reading approach was very beneficial as it resulted in substantial improvement in sophomore English majors' reading abilities. The findings also showed that most students in the experimental group had positive attitudes toward the program. Most importantly, after engagement in the program, those students developed a taste and habit for reading, which are of great importance for them to achieve their reading goals and proficiency in their future academic studies. Thus, the ER approach should be integrated into the reading curriculum of second-year English majors. As affirmed by Nuttall (1996), these two approaches to teaching reading - intensive and extensive reading - should not be seen in opposition, as both serve different but complementary purposes. If the program is effectively carried out, students are more motivated to read. "The more they are hooked on reading and read in quantity, the more optimal benefits in promoting reading competence they will obtain" (Renandya, 2007, p. 144).

\section{REFERENCES}

Baker, L., Afflerbach, P., \& Reinking, D. (1996). Developing engaged readers in school and home communities. Routledge. https://doi.org/10.2307/358410

Bassett, J. (2010). A series editors' view. In R. Day et al. (Eds.), Bringing extensive reading into the classroom. Oxford University Press. 
Cho, K. \& Krashen, S. (1994). Acquisition of vocabulary from the Sweet Valley Kids series: Adult ESL acquisition. Journal of Reading, 37(8), 662-667.

Day, R. R. \& Bamford, J. (1998). Extensive reading in the second language classroom. Cambridge University Press. https://doi.org/10.1177/003368829802900211

Day, R. R., \& Swan, J. (1991). Reading and spelling competence: Evidence from an EFL context [Unpublished manuscript]. Dissertation Abstracts International, 57, 1079-A.

Elley, W. B. (1991). Acquiring literacy in a second language: The effect of book-based programs. Language Learning, 41(3), 375-411. https://doi.org/10.1111/j.14671770.1991.tb00611.x

Elley, W. B., \& Mangubhai, F. (1983). The impact of reading on second language learning. Reading Research Quarterly, 19(1), 53-67. https://doi.org/10.2307/747337

Grabe, W., \& Stoller, F. L. (2011). Teaching and researching reading. Routledge.

Guthrie, J. T., \& Alvermann, D. E. (1999). Engaged reading: Processes, practices, and policy implications. Teachers College Press.

Guthrie, J. T., \& Knowles, K. T. (2001). Promoting reading motivation. In L. Verhoeven \& C. E. Snow (Eds.), Literacy and motivation. Routledge.

Hafiz, F. M., \& Tudor, I. (1989). Extensive reading and the development of language skills. ELT Journal, 43(1), 4-13. https://doi.org/10.1093/elt/43.1.4

Lai, F. K. (1993). The effect of a summer reading course on reading and writing skills. System, 21(1), 87-100. https://doi.org/10.1016/0346-251X(93)90009-6

Lituanas, P. M., Jacobs, G. M., \& Renandya, W. A. (1999). A study of extensive reading with remedial reading students. In Y. M. Cheah \& S. M. Ng (Eds.), Language instruction issues in Asian classrooms (pp. 89-104). International Development in Asia Committee, International Reading Association.

Masuhara, H., Kimura, T., Fukada, A., \& Takeuchi, M. (1996). Strategy training or/and extensive reading? In T. Hickey \& J. Williams (Eds.), Language, education, and society in a changing world (pp. 263-274). Multilingual Matters.

Nuttall, C. (1996). Teaching reading skills in a foreign language. Heinemann.

Pitts, M., White, H., \& Krashen, S. D. (1989). Acquiring second language vocabulary through reading: A replication of the Clockwork Orange study using second language acquirers. Reading in a Foreign Language, 5(2), 271-275.

Polak, J., \& Krashen S. D. (1988). Do we need to teach spelling? The relationship between spelling and voluntary reading among community college ESL students. TESOL Quarterly, 22(1), 141-146. https://doi.org/10.2307/3587067

Renandya, W. A. (2007). The power of extensive reading. RELC Journal, 38(2), 133149. https://doi.org/10.1177/0033688207079578

Richards, J. C., \& Schmidt, R. (2002). Longman dictionary of language teaching and applied linguistics ( $3^{\text {rd }}$ ed.). Pearson Education. 
Robb, T., \& Kano, M. (2013). Effective extensive reading outside the classroom: A large scale experiment. Reading in a Foreign Language, 25(2), 234-247.

Robb, T. N., \& Susser, B. (1989). Extensive reading vs skills building in an EFL context. Reading in a Foreign Language [Online], 5(2), 239-251. http://www.NetLibrary.com

Rodrigo, V. (1995, March). Does a reading program work in a foreign language classroom? Paper presented at the Extensive Reading Colloquium, American Association of Applied Linguistics, Long Beach, CA.

Rubin, A. (2013). Statistics for evidence-based practice and evaluation. Cengage Learning.

Seymour, S., \& Walsh, L. (2006). Essentials of teaching academic reading. Houghton Mifflin.

Taguchi, E., Takayasu-Maass, M., \& Gorsuch, G. J. (2004). Developing reading fluency in EFL: How assisted repeated reading and extensive reading affect fluency development. Reading in a Foreign Language [Online], 16(2), 70-96. http://www.NetLibrary.com

Tamrackitkun, K. (2010). Extensive reading: An empirical study of its effects on EFL Thai students' reading comprehension, reading fluency and attitudes [Unpublished doctoral dissertation, Rajamangala University of Technology Thanyaburi, Thailand].

Taylor, L., \& Adelman, H. S. (1999). Personalizing classroom instruction to account for motivational and developmental differences. Reading and Writing Quarterly, 15, 255-276. https://doi.org/10.1080/105735699278107

Waring, R., \& Takaki, M. (2003). At what rate do learners learn and retain new vocabulary from reading a graded reader? Reading in a Foreign Language, 15(2), 130-163.

\section{APPENDICES}

\section{Appendix A. Pretest (60 minutes)}

\section{PART 1: (8p)}

For questions 1-8, read the text below and decide which answer $(\boldsymbol{A}, \boldsymbol{B}, \boldsymbol{C}$ or $\boldsymbol{D})$ best fits each gap. There is an example at the beginning (0). Write your answer on the separate answer sheet.

\section{What is a coincidence?}

A coincidence is a surprising thing that happens to us. For example, two friends go shopping alone on the same day. When they (0)................up afterwards, they discover that they've each bought an identical T-shirt. Many people (1) .coincidences as significant or mysterious. But the simple (2) .... could be that friends tend to have similar taste in clothes. 
In reality, life is (3) of coincidences, but normally we don't notice them. For example, in almost fifty percent of all football matches, two players share the same birthday. This seems surprising, (4) that there are 365 possible birthdays in the year. But most of these matches will be played without anybody being (5) that the coincidence exists. (6) ..your birthday is today or tomorrow, you don't generally go around telling people when it is. What's more, without realising it, you probably (7) ...............into contact with lots of people born on the same day as you. But when a coincidence is (8) to your attention, it still seems amazing.
1. A. regard
B. think
C. consider
D. believe
2. A. explanation
B. definition
C. motivation
D. resolution
3. A. heavy
B. rich
C. full
D. crowded
4. A. given
B. except
C. even
D. instead
5. A. noticed
B. known
C. aware
D. intelligent
6. A. Therefore
B. Whereas
C. Meanwhile
D. Unless
7. A. make
B. come
C. have
D. go
8. A. taken
B. carried
C. brought
D. shown

PART 2: You are going to read an article about vegetarianism. For questions 914, choose the answer ( $A, B, C$, or D) which you think fits best according to the text. Write your answers on the separate answer sheet. (12p)

\section{Giving Vegetarianism a chance}

I don't consider myself to be a vegetarian, at least not in the strictest sense of the term. The two rules I follow as a semi-vegetarian - if that's even a proper phrase are that I never cook meals at home using meat, nor do I order meat dishes when dining out. Obviously, these aren't the only occasions when I have meals. My friends sometimes throw dinner parties and I wouldn't want to force my dietary beliefs upon them. So I eat whatever they prepare. If they've spent an hour roasting a leg of lamb or a side of beef, I can make an exception to my diet and tuck in along with the rest of the guests.

Mind you, I'm not offended by the taste of meat at all. On the contrary, I love the worst that meat has to offer - greasy hamburgers, savoury ribs dripping in barbecue sauce and thick, grilled steaks still pink in the middle. As a matter of fact, I grew up eating that kind of food. As an adult, however, I became more conscious of my eating habits. I started to consume less and less meat, until one day I found that I could go for months without eating any meals containing meat at all. I began to explore the idea of giving up animal-based foods altogether, just to see how I would get on. 
Soon enough, a whole new world of food opened up to me. I started eating a lot of vegetables and not just ordinary, tasteless salads tossed with a bit of dressing. I would steam broccoli and have it with rice and soy sauce. I would sauté courgettes and aubergines in olive oil and basil. I would try my hand at making vegetable soup with pasta, creamy mushroom soup and spicy cabbage soup (not one of my best creations, I'll admit). What I discovered is that maintaining a vegetarian diet is not only healthy, delicious and inexpensive, it's also abundant in variety. But there was one thing I couldn't quite shake from my mind - why isn't this way of eating more popular?

Even with all the health benefits of a vegetarian diet- lower risk of heart attack, prevention of high blood pressure, reduced rates of cancer - there still seems to be a complete lack of vegetarian eateries and a shortage of vegetarian options at most restaurants. I began to wonder if people were simply addicted to meat. That may be true for some, but for others who might give vegetarianism a try, I realised that there was something else in the way - the culture of vegetarianism appeared to be unpleasant. It seems that there are too many vegetarians who believe that their way of eating is superior to any other. They aren't just vegetarians, they're better people, or so they think. This is rather offensive. You walk into a vegetarian restaurant and suddenly you feel guilty for having eaten that chicken wing at your parents' house the week before. Even someone like me, who eats meat extremely rarely, feels a bit uncomfortable within that whole atmosphere.

So, I propose that we, the vegetarians of the world - again, assuming I can be considered a part of that group, or would even want to be - should become more relaxed about our meat-eating counterparts having a steaming cup of beef stew or sprinkling sliced chicken bits all over their salad, when and if they ever have one. Perhaps, if vegetarianism is seen to be an attractive alternative, more people might try it. It would be a shame for the idea to become trendy, only to go out of fashion in a few years' time. I suppose, for vegetarianism to take root in society for all to enjoy, it needs to change its image to one that is fun, inviting and worth following.

9. The writer eats his friends' meals because
A. he feels as though he's got no choice.
B. it doesn't violate any of his rules.
C. he wants to be a polite guest.
D. the taste of meat is appealing.

10. How did the writer give up meat?
A. He did it through a gradual process.
B. He just decided one day to give it up.
C. He set himself a goal of eating no meat.
D. He reverted to the eating habits of his childhood. 
11. In the third paragraph, the writer
A. talks about a few badly-prepared meals.
B. discusses the wide selection of vegetarian dishes available.
C. realises why vegetarianism isn't popular.
D. discusses the kinds of dishes he cannot eat.

12. The writer says the main problem with vegetarians is that they are
A. aggressive.
B. arrogant.
C. rude.
D. unsocial.

13. The phrase 'take root' in the last paragraph refers to vegetarianism becoming more
A. valuable.
B. fashionable.
C. exciting.
D. established.

14.The writer's purpose in writing this article is to
A. argue against the main point of discussion.
B. persuade readers to change habits.
C. provide information about a lifestyle.
D. express opinions and make suggestions.

PART 3: You are going to read an article about the history of environmental problems. Six sentences have been removed from the article. Choose from the sentences $A-G$ the one which fits each gap (15-20). There is one extra sentence which you do not need to use. Write your answers on the separate answer sheet. (12p)

\section{Waking up to environmental issues}

Jane Logue explains how the race to save the planet gathered speed.

It wasn't until around 200 years ago that we began to become seriously concerned about the negative impact that humans were having on the environment. There were two closely-related reasons for this realisation.

The first of these was that there was a significant rise in the population. Large numbers of people were now polluting our rivers and lakes, and cutting down our trees 15. Manufacturing processes caused 
people's health to suffer and we became aware of the damage being done to the landscape by activities such as deforestation, mining for coal and steel-making.

We could no longer close our eyes to the facts. There were simply too many people causing too much damage to our planet. Recognising the problem, the United States began creating National Parks. These were large areas of land where development and industry were not allowed. One of the people behind the setting up of the first National Parks was John Muir, an early environmentalist who also became president of the Sierra Club. 16.

Still operating today, the Sierra Club is active in many areas, particularly in campaigning to end our dependence on fossil fuels and to explore renewable energy sources such as wind and solar power. 17

But although several green organisations existed on both sides of the Atlantic in the first half of the 20th century, their power was limited.

In London in 1952, there was an incident that many say started the environmental movement. A combination of weather conditions and coal smoke led to several days of severe smog in England's capital. The consequences at the time seemed to be confined to traffic problems and cancelled sporting fixtures due to poor visibility. However, it soon became clear that thousands of people had died as a direct result of the air pollution in that short period of time. $\mathbf{1 8}$

Since the 1950s, however, our planet has had to face a range of new threats. For example, the widespread use of pesticides in the US inspired a book by Rachel Carson in 1962 called Silent Spring, which became a bestseller. 19.

Meanwhile, the World Wildlife Fund (WWF) was established to protect the habitats of wild animals and stop endangered species from becoming extinct. The development of nuclear weapons and nuclear power led to the forming of groups such as Greenpeace, and a series of well-documented oil spills helped draw attention to the environmental catastrophes that humankind was capable of bringing about. 20. Acid rain, the hole in the ozone layer and genetically modified crops have given rise to a vast number of organisations dedicated to limiting the damage. But, even with thousands of green organisations in the UK alone, it's tempting to wonder whether the race to secure a better future is one that we are winning.

A. In the UK, it wasn't until the 1950s that the first National Park was set up.

B. Today, we have no shortage of environmental concerns, or of groups committed to dealing with them.

C. The other key factor was the rise of industry.

D. Here too, the Americans were far behind the rest of the world. 
E. The popularity of this publication showed just how many people were against interfering with the natural balance of nature.

F. This was founded in 1892 and was one of the first environmental organisations in the United States.

G. The city was forced to face up to its problems, and action was taken to make sure such a tragedy would not happen again.

PART 4: You are going to read an article about technology in the home. For questions 21-30, choose from the texts (A-D). The texts may be chosen more than once. Write your answer on the separate answer sheet. (10p)

Which text...

21. mentions the variety of different appliances available?

22. explains how one device can be used instead of many others?

23. emphasises how much people in the past would have liked this modern appliance?

24. compares a domestic appliance to something used for road maintenance?

25. says that a domestic task in the past required a great deal of physical strength?

26. mentions how the most up-to-date homes are now organised?

27. contrasts the ecological benefits of a modern appliance to methods of the past?

28. refers to an appliance from the past that took a long time to prepare before it could be used?

29. makes a prediction about a particular device?

30. describes a modern appliance as being similar to a servant?

\section{The Road to Domestic Bliss}

How has household technology revolutionized life in the home?

\section{A. The washing machine}

In days gone by, there were few chores more backbreaking than doing the laundry. For centuries, heavy, wet clothing and sheets had to be cleaned by hand with no other help than a washboard and a mangle. These were the nearest thing to a washing machine and a dryer. The washboard was simply a board with ridges on it that made scrubbing clothes easier and a mangle used two rollers to squeeze excess water out of cloth, a bit like a steam roller that is used to flatten the tarmac on highways! 
But there is simply no comparison between a washboard and mangle and a modern washing machine. Not only is the washing machine highly efficient and easy to use, it also saves on water, so it is more environmentally friendly than washing by hand. There is little doubt that the housewives of the past would have been delighted to use a modern washing machine with its wide range of washing programmes.

\section{B. The cooker}

You could say that choosing a cooker is as complicated as deciding what kind of car to get these days. There are so many different types of cookers and ovens - gas or electric, with or without a fan oven, a microwave oven with or without a conventional grill. The list of features is endless and, just as is the case for so many household appliances these days, many use digital technology and are computerised, too.

It's a far cry from the days when a pot was hung over a fire or when the cook had to use wood or coal to light a stove or cooking range and heat it for hours before it could even be used. Now cookers heat up instantly and many of the latest models can even be programmed to turn themselves on and off when you're not there.

\section{The vacuum cleaner}

Wall-to-wall carpets are now a feature of many homes but they would be very difficult to keep clean, if it weren't for vacuum cleaners. The first electrical carpet cleaners using suction appeared at the beginning of the last century and have undergone many refinements since then. Advances in robotics have resulted in vacuum cleaners that can clean all the rooms in a house without the need for a human to operate them. They are like a high-tech housemaid and have proved a real laboursaving device for families everywhere.

Before vacuum cleaners became available and affordable for all, cleaning rugs and carpets meant either sweeping them with a stiff brush or hanging them over a line outside and beating the dirt out of them with a large stick or wooden paddle. You needed the muscles of a weightlifter to get your carpets clean back then. Today, you hardly have to lift a finger.

\section{The computer}

Now found in nearly every home, the computer is the device that has had the most revolutionary effect on how we lead our lives. And just as it has affected today's domestic technology, so too will it affect the domestic appliances of the future. Computers have begun to replace many other devices around the home, making them obsolete. Computers are increasingly used for entertainment and communication, for shopping and work and as a way of controlling other systems and devices in the home. Who needs all those gadgets of the past, such as a sound system or DVD recorder, when the computer can perform all their functions and more? State-of-the-art homes now use computer technology to run almost every aspect of domestic life, from controlling the 
heating to automatically ordering food from the supermarket. And computers are likely to play an ever- increasing role in how we run our homes in the future.

\section{Appendix B. Posttest (60 minutes)}

\section{PART 1: (8p)}

For questions 1-8, read the text below and decide which answer (A, B, C or D) best fits each gap. There is an example at the beginning (0). Write your answer on the separate answer sheet.

\section{Vera Neumann: fabric designer}

Vera Neumann was a designer and businesswoman whose products (0) their way into the homes of people across the USA.

Vera was born in Connecticut in 1907 and showed artistic (1) from an early age.

After attending art college in New York, she got a job as a textile designer, but didn't like being (2) what to do. Determined to develop her own styles, Vera started to produce tablecloths each item printed by hand in her kitchen.

But it was her scarves that (3) Vera's name. Good fabric was in short (4) during the Second World War, but Vera was lucky enough to (5) .across some silk left over from the manufacture of parachutes. Vera used it to design scarves with floral, abstract and geometric designs. These were an (6) .success when they appeared in department stores and during the 1950s they were the $(7)$ .of fashion, being worn by celebrities such as the film star Marilyn Monroe. By 1960, the company which Vera had (8) was employing 200 staff and producing 130 patterns per season.

1. A. training

2. A. led

3. A. got

4. A. supply

5. A. fall

6. A. acute

7. A. height

8. A. worked out
B. talent

C. expect

D. gift

B. directed

C. told

C. gained

B. did

B. availability

B. come

C. quantity

C. happen

C. instant

C. top

C. carried off

D. forced

D. made

D. delivery

D. run

D. extreme

B. peak

B. put on 
PART 2: You are going to read an article about a woman who found fame. For questions 9-14, choose the answer ( $A, B, C$, or D) which you think fits best according to the text. Write your answers on the separate answer sheet. (12p)

\section{Katie's Journey to Fame}

Katie Kirkland wasn't what you would call celebrity material. She was of average height and slightly plump, with pale skin and dark, shoulder-length hair which she sometimes dyed light brown when she felt like doing something special for herself. She worked at a petrol station selling petrol, a job which she had done for the better part of her 35 years of life. She had a pleasant, round face with freckles. She was a sociable person with a warm smile and well known in her small town, mainly for her ability to sing. That was the one superstar trait Katie would ever possess.

On a chilly afternoon in March, a man pulled into Katie's petrol station to buy petrol. Katie, particularly cheerful that day, assisted the man by filling his car. She hummed a few lines of the Rolling Stones' Satisfaction while holding the petrol nozzle. The man, who recognised the famous tune, started singing the words. Katie joined in and the two of them sang the whole song together and had a great laugh. 'You've got an amazing voice. You really stand out from the crowd! Why are you working here?' said the man.

'Oh, thanks, but you know, I'm just a small-town girl. I'm not the celebrity type,' Katie replied with a shy smile.

The man left and returned the next day with a friend, a slim, tanned and welldressed man, who asked Katie to come to his recording studio in the city. 'We'll arrange everything for you. We'll pick you up, record some songs and if at any point you don't feel comfortable about anything, we'll call it quits, no worries.' Katie was thrilled at the opportunity to show off her talents. She made arrangements to take a day off from work, travelled to the studio and recorded a few songs.

'You're absolutely brilliant! You've got to make an album. You're going to be a huge star, Katie!' exclaimed Mr White, the studio owner, who had taken to her straight away. Katie was beside herself with joy.

She took leave from her job and, over the next three weeks, she worked fulltime recording songs. The studio owner set up a band and they recorded 12 songs. After a month of editing, the album hit the record shops and Katie's music caught on right away. Presenters on morning television programmes wanted to interview Katie and have her perform. As exciting as it all was, Katie felt reserved, as she didn't feel confident about her looks. The studio did its best to dress her up like a star, but she still didn't quite look the part. Critics praised her singing abilities but media criticism was harsh, even unfair, regarding her appearance. Nonetheless, Katie had an instant fan 
base, full of people who could relate to her normal looks and down-to-earth personality. However, the attention came at a steep price.

In a matter of months, Katie's life had gone from a simple, quiet existence to a thrilling wild ride and finally to what she considered to be a terrible curse. It wasn't what she had signed up for. The fans, who once were just adoring and appreciative, had turned into a mob. When Katie showed up for performances, people wanting autographs and photographs would swarm around her. They would come to her house at all hours of the day, hoping to catch a glimpse of her. Photographers began to publish unflattering pictures of Katie, which upset her beyond belief. Just when she thought she might go mad, she decided to take over the reins of her own life. With millions of pounds in album sales, Katie, taking the tanned man's words to heart, decided it was time to get away from celebrity life. She tearfully left her house, her friends, her whole life behind. The papers circulated headlines screaming 'Where's Katie?' but no-one could find her. Katie had decided her $\mathbf{1 5}$ minutes of fame were over. So soon after becoming a star, she travelled far, far away, where the burning lights of fame would never find her again.

9. What extraordinary feature does Katie have?
A. her hair style
B. her personality
C. her voice
D. her work ethic

10. Katie's response to the man's compliment was.......
A. reserved.
B. cheerful.
C. annoyed.
D. hopeful.

11. What do we learn about the tanned man's offer?
A. It was an offer Katie couldn't refuse.
B. There seemed to be a hidden agenda.
C. Katie was under no obligation to the man.
D. There were some things left out.

12. What was the reaction to Katie?
A. She received only positive reviews.
B. People thought her singing wasn't very good.
C. Her fans didn't like her appearance.
D. There was a mixed response. 
13. Katie's stardom soon became...
A. a dream come true.
B. a real nightmare.
C. a rags-to-riches story.
D. a boring and dull task.

14. The phrase ' 15 minutes of fame' in the last paragraph refers to
A. the exact amount of time Katie was in the spotlight.
B. the length of time that it took Katie to decide to leave.
C. the length of one of the songs from her album.
D. the short amount of time Katie spent as a celebrity.

PART 3: You are going to read an article about the history of higher education. Six sentences have been removed from the article. Choose from the sentences $\boldsymbol{A}-\boldsymbol{G}$ the one which fits each gap (15-20). There is one extra sentence which you do not need to use. Write your answers on the separate answer sheet. (12p)

\section{Is Higher Education for Everyone?}

Everyone tells you the same thing - work hard at school so that you can go on to study at a university or college. It seems to be sensible advice. After all, the more qualified you are, the better chance you have of getting a good job, right? Higher education is always a good thing, isn't it?

Firstly, it depends on what you're planning to study. In terms of being employable when you graduate, the different branches of medicine, including dentistry, are probably the safest choices. Some studies show that close to $100 \%$ of graduates in these fields found a job within six months. $15 \ldots \ldots \ldots \ldots \ldots \ldots \ldots \ldots \ldots$

On the other hand, if it is your dream to study history or sociology, you need to be aware that, at the moment, you are less likely to find a job if your degree is in

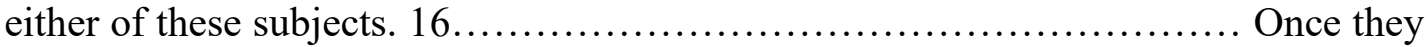
graduated, many were unable to find work. Others were forced to undertake more years of study or retraining in order to enter the job market.

Degrees related to business and management are among the most popular at the moment, which means there is a great deal of competition for places both at university and at work. So you may not find a place on your chosen course and, if you do, you will graduate with the same qualifications as thousands of other people. To avoid this you might consider studying more specialised subjects such as waste management or environmental management. They may not be your first choice but they are among the newer kinds of courses on offer which could well lead to a good job. 17 
Because, let's face it, not everyone is suited to another three or four years of study. Some people are better off not continuing their education. 18.

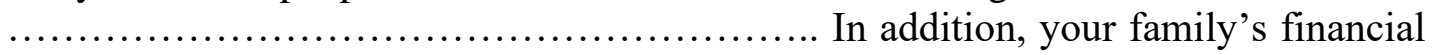
circumstances might make it difficult to go away to study. Furthermore, some people simply can't afford the expense of it all.

This brings us to the all-important subject of money. The average graduate with a bachelor's degree owes in excess of $£ 15,000$ and this figure is increasing every year. If one also considers the fact that he or she typically has to wait at least three months before he or she starts earning, you can see that spending those extra three or four years actually earning money can make quite a difference. 19

Of course, despite all this, there are still many benefits of studying at degree level. 20. And graduates usually get paid higher salaries. In the end, the advice to work hard at school is sound advice. Noone in their right mind would tell you to do the opposite. Leaving school with good qualifications will at least give you more options. What you do with those options is up to you. life studying

A. However, you have to ask yourself if it's worth spending several years of your something that is less than ideal for you.

B. If you can find a job at 18 (or, why not, at 16), then you could end up being much more financially secure.

C. Law graduates were similarly successful, so if these subjects are really what you want to study and you can get a place on a course you are lucky.

D. These include people who suffer terribly from exam nerves, and those who find academic work really difficult.

E. This would mean moving to the other end of the country or even to a different country altogether.

F. A degree that is not in demand is practically useless, as many recent graduates have found out to their cost.

G. A large number of employers look for some evidence of higher education.

PART 4: You are going to read an article about fathers and son. For questions 21-30, choose from the texts $(\boldsymbol{A}-\mathrm{D})$. The texts may be chosen more than once. Write your answer on the separate answer sheet. (10p)

\section{Which person's father ...}

21. always had faith in his son's abilities? 
22. encouraged his son not to give up in the face of disappointment?

23. gave his son advice in a light-hearted way?

24. made his son realise the need to try harder?

25. may not have succeeded in passing on certain ideas to his son?

26. never blamed his son for mistakes that he made?

27. put no pressure on his son to follow in his footsteps?

28. reassured his son when equipment let him down?

29. showed his son how to perform practical tasks?

30. was willing to listen to his son's suggestions?

\section{What's the best advice your father ever gave you?}

We asked four successful young men.

\section{A Tony: Racing driver}

'Drive it like you stole it and keep it on the black stuff!' I was quite nervous when I first started racing, but those were my dad's jokey words of wisdom and they made me feel better at the time. In the beginning, I had quite a few spins on the circuits - the very first one was particularly scary because the car left the track, but he never said it was my fault. I used to drive a Porsche 924 and pretty much every single race something would break, but Dad would just say: 'Don't worry about the car, we can always fix it.' I didn't like people behind me when I went round corners, but Dad was always telling me not to take any notice, to focus on what I was doing. I've got a long way to go, but Dad's really good - he's hardly the most polite person to have around if things don't go well, but he's my role model.

\section{B David: Record producer}

Because Dad and I have always been close, there was no one moment when he imparted some big philosophical piece of advice. I think his greatest gift has been his general unwavering belief in me. Since I was about fourteen, he's given me the opportunity to input ideas and have my say about the bands we work with or the equipment we use, which is amazing. When you're part of a family business, it can sometimes feel as if you have to be there, but my brother and I have done other things, and we're back with Dad again because we want to be. He left the decision to us. Dad's also been good at giving career advice because he's done it and he's got the experience. He's given me that drive and ambition to succeed.

\section{Andy: Buyer for a department store}


I was probably Dad's most unruly son. He tried to teach me a lot of things - how much I've taken on board is another matter. But I don't think I'm such a disappointment to him! He's a very cool dad, but he's quite traditional in some ways. He's always said that if you want to succeed, then get on with it. If you're going to do something, do it right away or at least write it down so you don't forget! I'm proud of my dad and how hard he worked for us to have a lovely childhood and good lifestyle. Dad also taught me valuable skills like how to change the oil in my car, how to play tennis and ski - although the last time he saw me doing that he said he feared for his life!

\section{Simon: Rugby player}

He had this catchphrase: 'Under-prepare, and you prepare to fail.' I heard it time and again. A typical teenager when things went wrong, I was always trying to blame everything and everyone but myself. He used his catchphrase and explained that if you don't put sufficient effort in, you'll never get anything out of whatever it is you're doing. That's stayed with me ever since, even now when I'm playing professionally. He's always given a fair amount of advice. He made me realise that if you just stick at something, no matter how hard things get, then your time will come. It's the hardest thing to hear when things aren't going well. At the beginning of the season, I wasn't getting picked for many matches. Then when the chance came to play, I really took it.

\section{Appendix C. Converting test scores to CEFR Levels}

\section{Cambridge English Cambridge English First

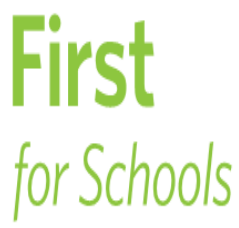

\section{Reading}

The Reading section consists of Parts 1, 5,6 and 7 of the Reading and Use of English paper. Correct answers in Parts 1 and 7 are worth 1 mark each. Correct answers in Parts 5 and 6 are worth 2 marks each. There are 42 possible marks in the Reading section.

\begin{tabular}{|c|c|c|}
\hline Practice test score & $\begin{array}{l}\text { Cambridge English } \\
\text { Scale score }\end{array}$ & CEFR Level \\
\hline 37 & 180 & Level C1 \\
\hline 24 & 160 & Level B2 \\
\hline 16 & 140 & Level B1 \\
\hline 10 & $122^{\star}$ & - \\
\hline "minimum score reported for first & & \\
\hline
\end{tabular}

Source: Cambridge English Language Assessment. 


\section{Appendix D. Er attitude questionnaire}

\section{ER ATTITUDE QUESTIONNAIRE}

This questionnaire aims to find out what you think and feel about the additive ER programme, the improvement or benefits you gained and any problems you encountered after engaging in it. We would appreciate your help to complete this questionnaire. Your response will be used for the purpose of the study only and your information will be kept confidential. Therefore, be honest and complete when you answer the questions. Your feedback is genuinely important to our research.

\section{PART 1:}

Please tick $(\sqrt{ })$ the box that shows your opinions after being exposed to the Additive Extensive Reading Program.

\section{Strongly disagree $=1 ;$ Disagree $=2 ;$ Neutral $=3 ;$ Agree $=4 ;$ Strongly agree $=5$}

\begin{tabular}{|c|c|c|c|c|c|}
\hline & 1 & 2 & 3 & 4 & 5 \\
\hline $\begin{array}{l}\text { 1. Reading graded readers helped me build a large sight vocabulary } \\
\text { (words recognized automatically). }\end{array}$ & & & & & \\
\hline 2. Reading graded readers was enjoyable. & & & & & \\
\hline $\begin{array}{l}\text { 3. Reading extensively helped me enhance grammar knowledge(tense, } \\
\text { structure development). }\end{array}$ & & & & & \\
\hline 4. I could get the gist of graded readers after engaging in this ER program. & & & & & \\
\hline $\begin{array}{l}\text { 5. I could broaden experience with textual organization through extensive } \\
\text { reading. }\end{array}$ & & & & & \\
\hline $\begin{array}{l}\text { 6. I felt sure about my own ability to read after participating in this } \\
\text { extensive reading program. }\end{array}$ & & & & & \\
\hline $\begin{array}{l}\text { 7. I could bring out more prior knowledge into reading comprehension } \\
\text { when reading graded readers. }\end{array}$ & & & & & \\
\hline 8. I enjoy reading more of the books in this extensive reading program. & & & & & \\
\hline 9. I could expand background knowledge by reading graded readers. & & & & & \\
\hline 10. Reading a lot in English helped me make reading a daily practice. & & & & & \\
\hline $\begin{array}{l}\text { 11. By reading extensively, I could apply the reading skills and strategies } \\
\text { I studied in the intensive reading program. }\end{array}$ & & & & & \\
\hline 12. Having access to the graded readers, I was enthusiastic about reading. & & & & & \\
\hline 13. I could improve reading skills and strategies by reading extensively. & & & & & \\
\hline $\begin{array}{l}\text { 14. I could make reading a daily routine and take the quizzes at the proper } \\
\text { time thanks to MReader. }\end{array}$ & & & & & \\
\hline $\begin{array}{l}\text { 15. Reading extensively helped increase my exposure to English, i.e. more } \\
\text { reading practice }\end{array}$ & & & & & \\
\hline
\end{tabular}




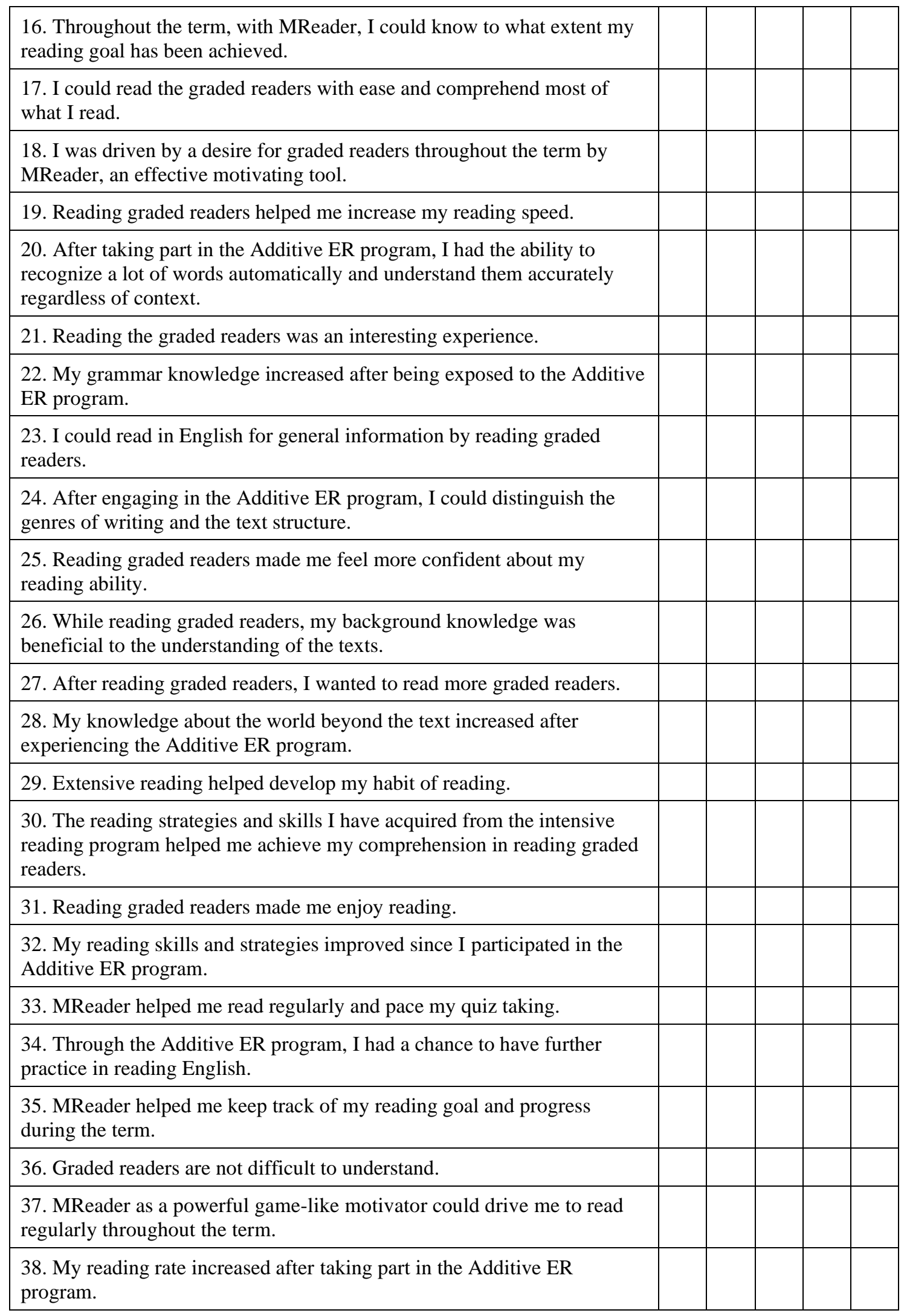


PART 2: Please identify any problems or difficulties you have encountered while reading graded readers or using MReader in the ER program.

\section{PART 3:}

Do you have any comments or suggestions regarding how we could improve our ER program? If yes, please write them down in the box below.

Thank you for taking the time and effort to complete this questionnaire. 